Meta

Journal des traducteurs

Translators' Journal

\title{
Nodes and Boundaries of Global Communications: Notes on the Translation and Dubbing of Audiovisuals
}

\section{Mario Paolinelli}

Volume 49, numéro 1, avril 2004

Traduction audiovisuelle

Audiovisual Translation

URI : https://id.erudit.org/iderudit/009032ar

DOI : https://doi.org/10.7202/009032ar

Aller au sommaire du numéro

Éditeur(s)

Les Presses de l'Université de Montréal

ISSN

0026-0452 (imprimé)

1492-1421 (numérique)

Découvrir la revue

Citer cet article

Paolinelli, M. (2004). Nodes and Boundaries of Global Communications: Notes on the Translation and Dubbing of Audiovisuals. Meta, 49(1), 172-181.

https://doi.org/10.7202/009032ar
Résumé de l'article

La qualité du doublage est menacée, en Italie et sans doute ailleurs, par les transformations du marché de l'audiovisuel. Les partenaires de l'industrie cinématographique (studios, metteurs en scène, traducteurs, directeurs de doublage) doivent se battre pour avoir le droit à un doublage de qualité. L'auteur propose quelques actions en ce sens. L'absence de règles a de graves effets sur les droits légitimes des cinéastes, sur le professionnalisme des agents techniques et artistiques, sur la langue d'arrivée et, par dessus tout, elle affecte les spectateurs, y compris les enfants. 


\title{
Nodes and Boundaries of Global Communications: Notes on the Translation and Dubbing of Audiovisuals
}

\author{
MARIO PAOLINELLI \\ Vice-President of AIDAC, Associazione Italiana Dialoghisti Adattatori Cinetelevisivi \\ (Association of Italian Translators/Dubbers for cinema and TV) \\ m.paol@aidac.it
}

\begin{abstract}
RÉSUMÉ
La qualité du doublage est menacée, en Italie et sans doute ailleurs, par les transformations du marché de l'audiovisuel. Les partenaires de l'industrie cinématographique (studios, metteurs en scène, traducteurs, directeurs de doublage) doivent se battre pour avoir le droit à un doublage de qualité. L'auteur propose quelques actions en ce sens. L'absence de règles a de graves effets sur les droits légitimes des cinéastes, sur le professionnalisme des agents techniques et artistiques, sur la langue d'arrivée et, par dessus tout, elle affecte les spectateurs, y compris les enfants.
\end{abstract}

\begin{abstract}
The quality of dubbing is threatened by the recent developments of the audio-visual market. This holds true in Italy and surely elsewhere. The actors of the film industry (studios, directors, dialogue-writers, directors of dubbing) must fight for the right to have "good" dubbing. Some proposals are given. The absence of rules is seriously damaging the moral rights of the original film-makers, the professionalism of the technical and artistic sector, the target language and above all viewers, including the children.
\end{abstract}

\section{MOTS-CLÉS/KEYWORDS}

dialogue-writer, dubbing, Italy, professionalism, quality

\section{The dialogue-writer: professional profile}

The Italian contract for film dubbing defines the dialogue-writer as: "The professional who translates and lip-synchs the dialogues of films for dubbing." In reality, this formula conceals the attempt, by the dialogue-writer, to replace the original dialogue with a different set of words, transposing them into another language. If we consider film language as a specialized form of "jargon" in which the meaning is created by combining words with gestures, and if we consider that every word acquires a heightened significance from the general context and the cultural complex embodied in the film as a whole, then what is recreated in each case is not just the sense of the text but rather the interwoven dialectic between words and images.

Translating a complex system like a film thus means taking it apart and reassembling it: i.e. redesigning it substantively, starting from its constituent parts, the web of meanings of words and images, separating them and then knitting them together to form another pattern, but one which is equivalent on the plane of expression and satisfying as communication, restoring the illusion of a comprehensible, seamless whole. 
In short, we can say that script adaptation for the purposes of dubbing is simply a bridge between different cultures and the dialogue-writer is the builder, the author of a three-dimensional translation.

\section{The dialogue-writer in the "dubbing chain"}

This image of a specialist writer who, with painstaking labour, hones language and synchronizes it, with mathematical accuracy (so to speak), so that it harmonizes with the predefined and immutable lip movements of the actors, seems, however, to conflict with the needs of the audiovisual industry for whom dubbing is merely an irritating and unavoidable collateral cost. Hence this profession all too often becomes something else, in which the only consideration is cost, speed of execution and the ability to deliver a product that does not actually invite criticism and avoids creating problems during production. In practice, the "good" dialogue-writer has to be concerned only to avoid creating hold-ups in a system that works to very tight deadlines. So in general the dialogue-writer most in demand is the one who will work for any figure, who works at a hectic pace, and delivers an average, standardized product, without frills and without bothering about the subtleties of language. At the same time, as predicted by Gresham's law ("bad money drives out the good"), the serious professionals are being forced out of the sector. The dialogue-writer required by the market, in other words, has to try not to "disturb" either the dubbing operations or the viewers.

Here we have a textbook example of a deregulated market in which the quality factor is both subordinate and directly proportional to the cost of production and the time spent on the job.

Traditionally in Italy the dubbing firms have their headquarters in Rome (some 90\%), but there are also some in Milan, a couple in Turin, and one in Bologna. It should be said that in recent years companies have sprung up that work below cost. This trend is now expanding with groups coming in from abroad that manage the multilingual versions of audiovisuals for transmission via satellite. These are companies that succeed, with various dubious stratagems, in knocking down production costs, clearly to the detriment of quality. But this seems to hardly matter to certain viewers and certain clients. Perhaps the makers of the original film would be concerned about the quality factor but they are physically at a distance from the scene of the crime, unaware of what is being done to their works. Consequently even dubbing firms that were previously able to offer a high-quality product, squeezed by fierce competition, have lowered their standard.

Unless measures are taken, like the creation of a professional list of dialoguewriters qualified to work on products for minors and the decision to open a Register of Dubbing Firms by the Communications Authority, after laying down precise rules for access and expulsion, the situation will soon become intolerable. To express it more clearly: possibilities are now opening up for work in the field of new broadcasting technologies, such as satellites, the information highways that need to be given an audiovisual and multimedia content, almost all of which need to be translated adapted and dubbed or subtitled. But the problem is: what is going to become of quality in a deregulated market of this sort? One example: some international translation agencies approach language students and offer them $8 \%$ of what a professional 
gets for translating subtitles. Or again: a film clip has to be transmitted urgently and the script adaptation is divided between two or more dialogue-writers, which is like sharing out the translation of a novel among several translators with absolute contempt for coherence of the style.

\section{Hollywood vs. the rest of the world: the quality of dubbing}

One of the consequences of the present situation is that paradoxically the "care" devoted to art films - most European films, the American Independents, and the whole of the output of other countries - is on average inferior to that lavished on the big Hollywood productions.

The essential problem is the resources available. For instance: the European cinema in Italy sells about $11 \%$ of all tickets sold at the box office - a little less than one hundred million euros. American films have much greater drawing power. The distributors of American films, because of the "big" titles they control and skilful marketing, which makes these films attractive to cinemas, impose their products on the cinema chains. This, plus the fact they have big promotion budgets, means American films can grab over $70 \%$ of the market. The situation is completely different with European films. They arrive in Italy with small promotion budgets (the US majors invest $50 \%$ or more of the cost of a film on promoting it, European filmmakers no more than 6\%). So it's clear that a European distributor without a multinational behind him can't afford to spend big sums on dubbing, knowing he's unlikely to cover the outlay with revenues. The result is that films distributed by some of the American majors are generally better dubbed because they have a bigger budget and can go for quality. Concretely, this means a talented dialogue-writer is given all the time he needs to work on a text, with a talented director of recognized experience with a free hand to select actors exclusively on the basis of artistic merit and organize the phases of production to achieve a quality product, and not just to cut costs to the bone. In this case recording studios, technologies, and materials are all of the highest standard.

It is a complex problem and unfortunately one that's severely underrated. The only way to solve it is through the adoption of a "European cultural policy" that will foster a system of financing and dubbing films made in the European Union (as well as outside it). These often include art films which call for special care and attention. It's clear that local distributors will always want to chip away at the costs of adapting dialogues and dubbing them unless they have some guarantee they'll recoup the costs. The trouble is that to save chicken feed - because that's what it's all about they risk ruining works of artistic quality that cost millions to make. Some help in this respect comes from the European Union's Media Program, but so far it has been limited and badly organized.

It needs to be said: the solution to this problem can only be the creation of a "European Dubbing Agency" which, in addition to setting quality standards, will supply funds earmarked for the purpose and recoup the money spent by working with the agencies for the collection of royalties which control ticketing. It should be backed by a fund created from a quota of the VAT generated by screenings of films in all member countries of the European Union. This would guarantee high-quality dubbing of all films, including art films. Moreover it could lead to the creation of a 
European consortium of advertisers, managed by the above-mentioned Agency, to give direct support to dubbing of films of outstanding cultural importance.

And now, by way of contrast, here is an example of a senseless policy: the case of Italy. Our tax on film shows used to bring in over thirty million euros: if we had devoted just one-third of this figure to producing multi-lingual versions of our own films, we could have dubbed forty films a year into six languages, a global multilingual catchment area containing over a billion people, set against the fifty to sixty million potential viewers at present. Instead, the tax (9\%) was abolished as a nice gift to the cinema chains (which mostly screen American films and certainly haven't cut admission prices). Then the Cinema Committee of the Department for the Performing Arts killed a pilot scheme, formerly co-funded by the Italian Ministry of Foreign Affairs, which was planning experimentally to export to the United States a number of films dubbed into Spanish and English.

\section{Authors and dubbing: an unknown quantity}

Rumours of a general decline in the quality of Italian dubbing circulate not only on the grapevine among industry insiders and foreign directors or studios which, being unable to find their own dubbers to do the job, take the precaution of appointing people they trust to oversee the quality. But while the role of supervisor is fundamental in the technical coordination and organization of multilingual versions and to act as language consultants when necessary, the dialogue-writer has to be responsible for guaranteeing fidelity to the script, and the director of dubbing for the performance. Everyone should shoulder their own responsibilities and not start treading on each other's turf, otherwise we risk a general decline in quality. This is the only way dubbing can grow and perform its function. But this is something that the filmmakers should understand and enforce themselves. Instead here we encounter a certain resistance, revealing a tendency to underrate just what is involved in transposing a script from one language to another.

You come across the same kind of resistance among Italian and European filmmakers when you tell them they have to fight for the right to have their works dubbed properly on foreign markets. Cavani and Rosi, for example, have always stated this publicly, but there are others, like Loach and Almodovar, who shoot their mouths off against dubbing, yet they owe their success in Italy only to the dubbed versions of their films. Then there are others again, including exporters and institutions, who fail to see - in fact they wilfully refuse to understand - that dubbing is the only effective way to reach viewers in other countries. Well, the Italians had better not complain if their works abroad are only shown by film clubs and don't make a dime, while, if they don't like dubbing, European film-makers should at least have the dignity to make sure their films are not dubbed.

Of course the increase in the circulation of Italian and European films in other countries does not depend just on greater awareness (and AIDAC has undertaken a highly articulated project - see our website $<$ www.aidac.it $>-$ to re-launch, promote and distribute Italian films abroad), but at least an awareness of the importance of "localizing" films and audiovisuals would already be a big step forward. 


\section{A hoary (and boring) old question: to dub or not to dub?}

Back in the forties, Michelangelo Antonioni fought a battle against dubbing in the pages of "Cinema" magazine. This debate, now dated, is of purely historical interest. The issues then were totally different: at that time dubbing was still in its infancy. The debates on the subject produced valid and useful aesthetic reflections, but they were tarred by elitism and failed to look far enough ahead. And remember illiteracy rates in Italy were high at the time and so subtitles weren't really on the cards as an alternative. Today, what's more, data supplied by IEC/Lintas show that only one per cent of Italians understand a foreign language well enough to be able to follow a dialogue. It would be a good thing if film-makers finally embraced the third millennium, however belatedly, and thought hard about the problem. At any rate, all the directors who are against dubbing have used it, from Antonioni to Polanski, while the ones that still blast off against it as an infamous practice (including Loach and Almodovar, noted above) perhaps fail to realize that technology has now solved all the problems. The new DVDs (digital versatile disks) can contain up to eight dubbed and thirty-two subtitled soundtracks, so you just choose for yourself how you want to see them.

\section{The question of subtitles}

Subtitling is the technique that detractors of dubbing recommend as an effective way to solve the problem of understanding foreign-language films and audiovisuals. But this is to ignore their limitations, which are worth noting:

a) subtitling means reducing the original text by $40-70 \%$;

b) it disfigures the image;

c) the viewer spends about half the running time of a film reading the subtitles

d) continually switching attention to the bottom of the screen prevents any real involvement in the film;

e) viewers who know the original language are distracted by subtitles;

f) the fascination of hearing the actors' original voices is not perhaps sufficient reason for limiting the expressiveness of the work as a whole;

g) subtitles, given the preponderance of audiovisuals made outside Italy, give greater prestige to the language the work was produced in than the local language, and is hence a subtle form of linguistic and cultural colonialism.

These are the facts. Draw your own conclusions.

The system used in France involves the distribution of big successes in the original language in some cinemas and dubbed versions in others. This system allows viewers to choose how they want to see the film, and above all it enables industry insiders to judge the quality of dubbing in terms of translation. In Italy no one has ever tried this approach, so subtitling is limited to film festivals. This situation rests on a simple economic fact. There isn't a big audience for films with subtitles, especially "commercial" films. So hardly any distributors bother to supplement the dubbed version with a subtitled one. In big cities there are some cinemas that show films with subtitles; it's true they get an audience, but it is always the same audience that expressly wants to see subtitled films. The proportion of people who want to see undubbed films to dubbed is 20,000 to $1,000,000$, i.e. 3 or 4 percent. It's their right, of course, but it's a niche market. Why should a distributor shoulder the additional expense of subtitling, and without counting the cost of the extra copies? In Italy, until the law enforces it, no 
one is going to come forward and finance operations that are sure to lose money. Even those distributors who used to offer their audience original-language films, though they continue to do so, now dub all their imports.

Anyway, as already stated, the DVD means you have a full menu of choices and in future film-lovers are likely to give up going to the cinema and will simply wait for the DVD to come out.

Another point to remember is that subtitles also need to be assessed for quality, to prevent low-quality operations dictated mainly by the needs of the DVD industry, which wants to subtitle its global library into those distant tongues that are increasingly becoming markets. In Italy, as a first step toward regulating this sector, it's been decided to insert a specific article in the next national dubbing contract but it's clear that European regulation would be far preferable.

\section{The quest for quality}

So what's to be done to restore effective control over dubbing, to prevent badly dubbed audiovisuals from being distributed? In Italy, AIDAC, as the trade association, is already doing quite a lot. It has established rules, a code of conduct to safeguard the professionalism and hence the quality of the dubbed versions. At Cannes and Venice it has repeatedly launched appeals in four languages to film-makers worldwide, and these are published by the Artists Rights Foundation on their website. It has presented observations and put forward an amendment to the Italian law that regulates the system of communications ('Disciplina del sistema delle comunicazioni'). It has established quality of dubbing as one of the objectives specified in the service contract between the Italian State and RAI TV (the Italian public-service broadcaster). It is about to start professional refresher courses for its members and it has signed agreements with a number of Italian universities to institute post-graduate specialist courses. It is one of the associations "monitored" by the CNEL (the Consiglio Italiano per l'Economia del Lavoro) in expectation of its public recognition. It is working to fix UNI-ISO standards to certify quality. In short, things are moving, but it has to be said that we'd like to see more signs of interest from the Performing Arts Department (Dipartimento dello Spettacolo) which, together with the Media Authority (Autorità per le Comunicazioni) should, in our opinion, address the subject and lay down clear rules to protect the Italian language, film-makers, professionals in the sector and viewers, including, it should be stressed, minors.

The critics should be playing an important part in all this. In the late thirties, whenever Paolo Uccello published a review in the magazine Bianco \& Nero, he devoted a small space to the quality of the dubbing. But today, after decades when film critics either neglected the problem or else tackled it superficially or smugly, the result is the current decline in quality. Any real concern is very rare. At most you read short asides, which suggest nothing but prejudice, such as "of course it will be spoilt by dubbing," "unfortunately it will have to be dubbed" etc. In short, the outlook is bleak (and does little credit to the critics).

Today dubbing suffers from problems created by competition, the market. There are some players who, for the most disparate reasons, want to pay peanuts for dubbing jobs, so allowing unscrupulous non-professionals to undercut the market. Some of them, with complete impunity, are "re-dubbing" the great films of the past, works 
that made the history of the cinema (and of dubbing), working on the lowest levels, as if they were dealing with telenovelas. There are even films that are dubbed "East European-style," i.e. with just two voices, a woman's for all the actresses, a man's for the actors. In a panorama of this kind and with these features, anyone who cares about quality is totally uncompetitive.

All this works to the detriment of the final result and hence of the viewers, whether they watch films on TV or at the cinema. But it also damages the distributors who seem unable to understand that the value added to a film by dubbing is reflected in its earnings.

\section{Audiovisual communication in a world without borders}

In the movie industry, globalization of the market, with the fragmentation of broadcasting channels and hence a growth in demand, will probably lead to the distribution of products originating within the EU under a system of compulsory quotas. The Americans will probably be forced to backtrack or else increase the number of co-productions with European companies, so as to get round the nationality barrier. In reality, the craving for audiovisuals is so great there will be room for everyone. The issue is not to defend ourselves by raising further barriers but how to boost circulation outside the confines of Europe. This won't be a simple task but it is the only possible solution. And here we need to enter a caution. Perhaps it's not clear to everyone that, while the global reach of broadcasting spreads the illusion of a free, untrammelled and universal circulation of information and unprecedented growth in the potential for expression, the battle for the global economic and political balance-ofpower is being played out around the system of telecommunications. And estimates suggest this sector will be worth $10 \%$ of the global economy by 2005 .

From the 1970s to the present we have witnessed a progressive convergence in the industry, powered by takeovers, mergers and acquisitions, between the copyrightowners of the content (the "old" producers), the owners of access to the system (the distributors) and the sellers of access to the viewers. This strategic convergence is favoured by government policies - above all those of the US government -, which are demolishing all the barriers between the different sectors. What's more, it's clear that within a few years all the investments in the film industry will be made by companies with a stake in telecommunications while the traditional producers will be left with a marginal $16 \%$.

This redefinition of roles has more serious and far-reaching effects than might appear: the telecommunications companies are being transformed from neutral conveyers of content to producers of services, which means they decide which programs to produce and transmit. TV networks, in the meantime, by passing from traditional broadcasting (financed by advertising and/or a licence fee) to direct distribution, can enlarge their market by offering their product in forms better suited to the requirements of viewers. And since TV fiction takes the lion's share of advertising (a business that amounted to?20,000 billion worldwide in 1995), advertisers, faced with this epoch-making change, are terrified of the fragmentation of audiences, which will raise the contact-cost to critical levels.

This enormous enlargement of the cultural supply and demand, which is going to affect the very nature of audiovisuals, fails to guarantee a differentiated product or 
access for products that are uncompetitive to the market of the big players. Even less does it guarantee a concern for quality, which is certainly not what interests the shareholders in telecom companies which operate in sectors outside the cultural field and whose strategies are obviously focused on pure industrial profit.

In short, given this set-up, it is no longer possible to control the content. The content is now an industrial mass product with creativity subordinate to budgets and to distributional and promotional muscle.

The panorama ahead of us certainly shows alarming signs of a flattening of cultural identity. But it is a process that we have to govern instead of just caving in as if we were staring at the Apocalypse.

The European response of imposing compulsory quotas for European works to be transmitted on TV or the Spanish experiment of issuing "licence to dub" can be seen as no more than stopgap measures, though certainly useful to correct a market that, if left to its own "laws," ignores demands for authentic pluralism and the circulation of works that enshrine much of the national identity.

The point, as I was saying, is that we need to think less about protecting ourselves and more about moving dynamically on other markets, responding to globalization with the assertion of our "cultural difference." But it is also clear that the spread of Italian and European films abroad can only be achieved by a consortium of the leading distributors (on the model of Unifrance, active since 1994). This would provide for the "localization" I mentioned above (i.e. adapting the products to suit different linguistic and cultural zones). It would also circulate our motion pictures by controlling the rights to use for foreign markets, adopting a marketing strategy concerned not just with distribution to cinemas but above all with the new distribution systems which already exceed box-office revenues by over $200 \%$. Unfortunately the private sector in Italy, despite ample government assistance, with its provincial outlook and low profile, is incapable of moving effectively in this direction. This means strong and enlightened state intervention is necessary: both to safeguard with the help of the SIAE (Italian Association of Publishers and Authors) - the rights to use the works dispersed in the libraries of the entertainment multi-nationals, and also to secure the broadest possible dissemination of Italian culture worldwide. This measure can't wait, if we want to export an image of Italy that goes beyond Parmesan cheese and designer clothes, but above all - and this is what interests us all - if we want to stop being preyed on by others and instead become a dynamic player in the circulation of cultural products.

\section{Towards new rules}

The national contract for dubbers, which is at present the only point of reference for the sector in Italy, is about to move into a new phase. What about the further rules that need to be adopted to guarantee quality?

The recent reopening of negotiations with employers has revived the importance of the certification of firms and of working procedures in compliance with UNI rules. This is one plank in the union's negotiating platform.

The work of the commission set up to establish the framework for "quality standards" never went beyond the third meeting. In 1999 the UNITER company, which had been given the task of drawing up the standardization procedures, suspended 
work, justifying its action by the lack of interest on the part of employers. This clearly shows that there was no risk of clients having to pay higher prices for dubbing if the system were subjected to quality certification, and it was equally clear that this project was not (and is not) viewed favourably by those firms - the majority - that could never have come up to UNI standards.

Moreover, according to some observers, many firms that could have complied with the standards were (and are) not favourable to being subjected to these standards which they feared (and still do) will limit their room for manoeuvre on the market. Faced with this picture, it is inevitable to consider it extremely hard to tackle the subject by following the normal procedures. And so we have to think of an alternative, which will by degrees lead this market to adopt an effective system of standards to protect film directors, viewers, workers and the system of firms.

Point 2 of the supplementary minutes to the agreement underwritten by both parties, including clients, stated: "To achieve higher standards of quality, the corporations and the distribution and broadcasting companies, both Italian and foreign, are pledged to solicit prompt approval and application of UNI standards for the certification of dubbing firms and studios and to broadcast and/or distribute only those products that have been dubbed in compliance with these standards." Given this agreement, it is possible to foresee that at least in the first phase the unions and the trade associations, quite independently and through the formation of a committee for the purpose, after drafting a National Register of Dubbing Firms and Studios, will fix the parameters for the assessment of the firms, supervise their activities and periodically and publicly inform the clientele and operators in this sector of their findings.

Once the system is in place, there should follow a second phase in which by agreement between the firms and studios the procedures adopted are progressively transferred to the control of the UNI or the Societé Générale de Surveillance. The clientele's adherence to the use of this "list" will be assessed and used also at the negotiating table. At any rate, it will make for clarity and a greater sense of responsibility in the whole sector.

Finally, the sum of the data obtained, together with that hopefully provided by activating the Osservatorio della Commissione Paritetica di Vigilanza (Italian Observatory of the Joint Supervisory Committee) regarding flows of work and the identification of the "real clientele," will be of fundamental importance in monitoring distortions and developments in the market and setting up, in view of the renewal of the agreements, objectives and consequent political and trade-union strategies.

\section{Professional orders, registers, lists. Who defends the viewers?}

Some time ago, a bill was presented in the Italian parliament for the institution of a professional register for translators and interpreters. In this regard many commentators observed that the category of dialogue-writers should find a place in this "register" while others at once objected it was a form of "retrograde corporativism in a period of total globalization," meaning that all this is going against the current of a natural opening up of the market on all levels. So how can we reconcile the need for free choice for the clientele (producers and distributors of audiovisuals) with the safeguarding of the professional values of a category that receives very little consideration? 
To have a clear idea, it would be useful to stress that at present most of the films and series shown by the TV networks are dubbed. In this state of affairs, the total absence of rules in the sector - as we have said repeatedly - is having disastrous effects on levels of quality and seriously damaging the moral rights of the original film-makers, the professionalism of the technical and artistic sector, the Italian language, and above all viewers, including minors. The latest surveys show that in Italy children spend an average of $31 / 2$ hours a day in front of the TV set, watching material that is $90 \%$ dubbed (the European average is much the same). They are the ones who are being neglected. We are already present in this bill. And the reason that has led us to suggest a series of amendments to obtain a system of certification of professional quality lies in the need to offer viewers the guarantee that the transposition from one language to another has been carried out with complete respect for the original work and the Italian language. But our principal concern is for children who are great consumers of foreign audiovisuals, and this means we have to give priority to the objective of preventing any distortion or levelling-down of language and culture that could impede their developing powers of expression and cognition. I cannot see how anyone can oppose this objective and I believe that whoever decided to shelve this parliamentary bill will soon be compelled to revive it.

I said at the start that the dialogue-writer is rather like a bridge-builder. Well, I feel that no one complains too much, perhaps when crossing a wind-whipped bridge, if the engineers and architects have their respective registers. 